\title{
Social Capital, Entrepreneurship and Rural Development
}

\author{
G Prayitno $^{1 *}$, D S Noor ${ }^{1}$, and A R T Hidayat ${ }^{1}$ \\ ${ }^{1}$ Regional and Urban Planning, Universitas Brawijaya, Indonesia \\ *Email: gunawan_p@ub.ac.id
}

\begin{abstract}
Article Information
Received:

6 August 2019

Received in revised form:

28 November 2019

Accepted:

13 December 2019

Volume 1, Issue 2, December 2019

pp. $84-88$

CUniversitas Lampung

http://dx.doi.org/10.23960/jesr.v1i2.29

Abstract

Arjowilangun Village is one of the most significant areas of origination in the Malang Regency for Indonesian migrant workers aiming to work overseas. The remittance sent by Indonesian migrant workers can be utilised to support the Designative program, by establishing and developing entrepreneurship. The growth and development of entrepreneurship can be formed from the participation of the village community. Community participation in developing independent entrepreneurship can in turn boost village development. In line with Indonesian culture, rural communities still put forward kinship, trust, mutual cooperation, networking and high social norms (social capital component). This research aims to identify the social capital of retired Indonesian migrant workers and their decision to start business entrepreneurship. The results of the Social Network Analysis (SNA) as identified through three approaches: rate of participation, density and centrality showed that 14 respondents had the potential to be key figures in spreading information to increase community participation in village development. While the results of the correlation analysis indicate that the decision to start a business were influenced by the high value of their social capital, higher social capital can encourage the community to become entrepreneurs, enabling them to have a positive influence on village development.
\end{abstract}

Keywords: migrant worker, social capital, entrepreneurship, rural development

\section{INTRODUCTION}

$I^{N}$ NDONESIA as a developing country are faced with various problems, such as unemployment, poverty, and low-income rate. Reduction of unemployment can be made with an overseas employment placement program [1].

Malang Regency is the second largest regency placing Indonesian migrant worker abroad in East Java after Ponorogo Regency, with the number of overseas migrant worker are 50,617 people. One of the largest villages of origin of overseas Indonesian migrant workers in Malang Regency is Arjowilangun Village, Kalipare District [2].

As one of the areas of origin for Indonesian migrant workers in Malang Regency, Arjowilangun Village has the remittances that can be potentially utilized to support the Desmigrative program. Desmigrative program is the program that establishing and developing entrepreneurship. A study from Sander and Maimbo (2003) found that remittance sent by migrant workers to their home countries in Africa could keep the economy going in the area of origin and capable of advancing the country of origin [3]. In the other research, founded that business development or entrepreneurship and community empowerment are part of the driving force of economic development. Entrepreneurship also plays a role in accelerating equity in economic growth and can increase people's income, and provide employment and business opportunities [4].

Entrepreneurship development in Arjowilangun Village did not go hand in hand with the large number of Indonesian migrant workers. Presently, only 106 retired migrant workers have developed their businesses (entrepreneurs) out of a total of 562 retired Indonesian migrant workers in Arjowilangun Village [5]. In fact, according to other result, there are different kinds of experiences obtained, such as migrant labor skills and experience, can be applied to open a business in the area of origin [6]. 
Noting the significance of remittances for the welfare of Indonesian migrant workers (active and retired), this study intends to identify the magnitude of the influence of social factors on entrepreneurship decision in the village of origin. Social capital in the form of trust, norms and networks, are capitals that must be considered by entrepreneurs [7]. Social capital provides space and opportunities reasonably well in optimizing community empowerment and development program [8]. Other report stated that high social capital would increase the level of community participation in various forms. One form of community participation is growth and entrepreneurship development [9].

This study aims to identify the condition or social structure of retired Indonesian migrant workers in Arjowilangun Village. Social structure is "the whole system, network or pattern" of relationships. The network is interpreted as an interlocking relationship in which the interaction of an individual determines the interactions that occur on the other. The social structure formed can be identified from three indices to measure social capital, which includes the rate of participation, density and centrality [9]. The researchers also use correlation analysis to determine the factors that influence entrepreneurial decisions of retired Indonesian migrant workers.

\section{MATERIALS AND METHODS}

The type of data used in this study is quantitative and qualitative data. The type of data collection methods used is primary surveys and secondary surveys. The primary survey is carried out by interviewing retired Indonesian migrant workers. The analysis used in this study is Social Network Analysis (SNA) and correlation analysis.

Based on the data, there are 106 retired Indonesian migrant workers have become entrepreneurs in Arjowilangun Village, consisting of 65 men and 41 women. All of entrepreneur in this village are the respondent.

\section{A. Social Network Analysis}

Affiliation data is used as the input of social network analysis. There are two types of affiliate networks, namely one-mode networks and two-mode networks. Affiliation data can identify the relationship between actors or the relationship between events or the relationship between actors and events [10].

Affiliation data can report the presence of actors, membership or types of relational ties with an event [11]. The event referred to in this study is the membership or participation of retired Indonesian migrant workers who have become entrepreneurs in institutional events in the village. The following is an
Affiliation data management method in Social Network Analysis [12].

\section{B. Spearman Rank Correlation Analysis}

A correlation analysis aims to determine the pattern and closeness of the relationship between two or more variables [13]. The Spearman Rank correlation analysis is categorized as a nonparametric statistical analysis, which is used to analyse data ordinal scale and distribution of unknown or abnormal data. This analysis is used to measure the relationship between two variables that are not based on the actual data value pairs but based on rank

\section{RESULTS AND DISCUSSIONS}

\section{A. Entrepreneurship in Arjowilangun Village}

Entrepreneurs in this study are focused on those who have worked abroad as Indonesian workers or commonly called retired Indonesian migrant workers. According to the Republic of Indonesia's Board on National Entrepreneurship, entrepreneurs are Indonesian citizens who can creatively recognize and manage themselves, other opportunities and creative resources to create added value for themselves in a sustainable manner.

While entrepreneurship is the spirit, attitude, behavior, and ability of Indonesian citizens in handling businesses and/or activities that lead to efforts to find, create, apply the workings of new technologies and products by increasing efficiency to provide better services and/or obtain greater profits.

Entrepreneurship is a process of applying creativity and innovation in solving problems and finding opportunities to improve life [14]. The emergence of entrepreneurship is nothing but a result of imbalances in the labor market. In other words, the workforce that is not accommodated in the formal sector will be faced with two problems; they continue to be unemployed, or they have to open their own jobs called entrepreneurship. In the other report, stated four reasons for someone in becoming an entrepreneur, namely [15]:

a) Financial reasons, namely to make a living, to become rich, to seek additional income, as a guarantee of financial stability.

b) Social reasons, namely obtaining prestige/status, to be known and respected, to be a role model, to be able to meet with many people.

c) Service Reasons, namely giving work to the community, helping orphans, parents, create a future for the family.

d) Reasons for Self-fulfillment, to be superior/independent, to achieve something that is desired, to avoid dependence on others, to be more productive and to use personal abilities. 


\section{B. Types of Business}

Based on the interview results, the types of business activities carried out were mostly grocery store business with as many as 35 businesses, followed by a food business with as many as 15 , cosmetology \& beauty businesses as many as 10 , as well as businesses in the livestock business sector. The electricity, computer stores, tailors, internet cafes and, vehicle washing business each consists of only one entrepreneur each.

\section{Institutional/community groups}

There are 6 (six) community groups in Arjowilangun Village followed by respondents. The groups consist of 4 (four) types of groups, which include religious groups/organizations (Majelis Ta'lim and Majelis Gereja), Social groups/organizations (Panti Laras and PKK), Village Arts groups, and financial institutions (Koperasi Senang Hati). The community groups are including:

a) Majelis Ta'lim Al-Iman Arjowilangun Village is an association of Muslims who regularly hold religious activities every week and every significant day of Islam. The activities of the Ta'lim Council were attended by residents from all hamlets in Arjowilangun Village.

b) Church Assembly or Christian congregation routinely holds Sunday Service activities and mass (service in the member's house every other week) and activities on Christian religious holidays such as Christmas and Easter.

c) Panti Laras is another name for the association for older people. Panti Laras has activities such as elderly posyandu (Family Planning Services Post), elderly gymnastics, debriefing or mentoring of social organisations from outside the village and also celebrations of religious holidays and independence.

d) Family Empowerment and Welfare (PKK) is an institution engaged in empowering women to improve community welfare. PKK has activities within the RT (neighbourhood Association) such as dasawisma and also activities within the village area such as posyandu, coaching/counselling, environment (mutual cooperation) and also training.

e) Village Art Group of Arjowilangun Village that has various activities such as Malay orchestra, shadow puppets, cosidah and others. Members of village art groups are not limited by age, consisting of all ages ranging from children to the elderly.

f) Senang Hati cooperative as an institution that functions as a facilitator or liaison between banks and rural communities to assist business development at the micro level. At the beginning of its growth, the Senang Hati cooperative only focused on assisting retired Indonesian migrant workers, but in the long run, the Senang Hati cooperative will also assist the general public in the village, not only limited to the retired Indonesian migrant workers.

\section{Social Capital}

The role of social capital in economic development is as important as other economic infrastructure. It has been proven that economic growth is positively correlated with social capital. Social capital is a concept arising from a result of the long process of interaction in society. Although interactions occur for various reasons; the way people interact, communicate, and then establish cooperation is influenced by the desire to achieve common goals, different from personal goals.

Such interactions then create social capital in the form of emotional bonds that unite people to achieve a common goal, which then fosters trust and security created by the existence of relatively long relationships [4].

It has been defined somewhere that social capital as a characteristic of social organizations, such as networks, social norms and beliefs, which facilitate coordination and cooperation for mutual benefits [16]. Also, other results views social capital as resources that are accessed by individuals and groups in a social structure, which facilitates cooperation, collective action, and the maintenance of norms [17].

Social capital owned by the community, such as trust, mutual cooperation, networking and attitude, significantly influences the development of entrepreneurial behaviours, such as increasing public trust manifested in honest behaviour, orderly behaviour and cooperation based on shared norms. In entrepreneurial activities, social capital can also function as a lever of the success of business activities, as social capital has cooperation values.

\section{E. Social Network Analysis (SNA)}

The following is the result of the Social Network Analysis (SNA), using the UCINET version 6.0 program.

\section{Rate of Participation}

The results of the calculation of the retired Indonesian migrant workers participation rate in Arjowilangun Village showed a value of 2.23. These calculations show that each respondent on average followed 2 to 3 institutions from the six existing institutions. The value of 2.23 indicates the retired migrant worker's participation rate is in the medium category, which means the respondents in this study were familiar with and had obtained information from each other as they had equal participation from several institutional activities in the village. 


\section{Density}

The result of the calculation of density put its values in the high category, which is 0.86 . This shows that $86 \%$ of the respondent followed the same institution. The high-density value indicates a high level of interaction between respondents in Arjowilangun Village. It means that when the retired Indonesian migrant workers turned entrepreneurs often interact; it is easier to build trust between them.

\section{Centrality}

The analysis showed that five respondents had a low degree of centrality value, five respondents had a moderate degree centrality value, and 96 respondents were classified in the high degree centrality value. A total of 100 respondents had a high value of central closeness, four respondents had a moderate closeness centrality value, and none was classified as low. Whereas for the between ness centrality, all respondents are included in the low category.

Social Network Analysis (SNA) as identified through three approaches: rate of participation, density and centrality showed that 14 respondents had the potential to be key figures in spreading information to increase community participation in village development.

The results of the social network analysis found that the social capital was characterized in the type of social typology of bonding or also known as a characteristic of a sacred society. Bonding social capital tends to be exclusive; the basic characteristics inherent in this typology are more inward looking.

\section{F. Spearman Rank Correlation Analysis}

The correlation coefficient value shows that the relationship direction is a direct correlation or inverse correlation. Thus, the interpretation of the correlation model is as follows:

a) Financial reasons (X1): it appears that the value of correlation coefficients between financial reasons and entrepreneurial decisions is 0.402 . This shows that the strength of the relationship between the two variables is quite strong. The relationship between financial reasons and entrepreneurial decisions has a positive correlation, which means that the higher the value of financial reasons for a retired migrant worker, the higher the interest and the possibility of the migrant worker in deciding to become an entrepreneur.

b) Social reasons (X2): it appears that the value of correlation coefficients between social reasons and entrepreneurial decisions is 90.85. This means that the strength of the relationship is very strong. It shows the relationship between social reasons and entrepreneurial decisions being a positive correlation. The higher the value of social reasons for a retired migrant worker, the higher the interest and the likelihood of a migrant worker deciding to become an entrepreneur.

c) Reason for service (X3): it appears that the value of the correlation coefficient between the reason for service and entrepreneurship decision is 0.840 . This means that the relationship between the two variables is very strong. It shows the relationship between service reasons and entrepreneurial decisions being a positive correlation. The higher the value of service reasons for a retired migrant worker, the higher the interest and the possibility of the migrant worker in deciding to become an entrepreneur.

d) Reasons for self-fulfillment (X4): it appears that the value of the correlation coefficient between the reasons for self-fulfilment and entrepreneurship decisions is 0.181 . This means that the relationship between reasons for self-fulfilment and entrepreneurial decisions is a positive correlation. The higher the value of the reason for the selffulfilment of a retired migrant worker, the higher the interest and the likelihood of a migrant worker in deciding to become an entrepreneur. The significance value can also determine the presence or absence of the relationship between social/social capital reasons (X2) on entrepreneurial decisions (Y).

Based on the results of the Spearman Rank correlation test, the significance value of social capital (X2) on entrepreneurial decisions is equal to 0 (less than 0.05). This value means that there is a relationship between social capital towards the decision of retired Indonesian migrant workers in becoming entrepreneurs at the study location.

\section{CONCLuSions}

The results of the calculation of the rate of participation of retired Indonesian migrant workers in Arjowilangun Village using the SNA analysis showed that the participation rate was in the moderate category. This shows that the respondents in this study had the same participation from several institutional activities in the village. The density result, used to determine the level of interaction among the respondents, were categorized as high as the interaction of the entrepreneurs can increase and build trust between them. The results of the analysis of the level of centrality were categorized as high. This indicates that there is a high community enthusiasm or participation with institutional activities in the village with $91 \%$ of the respondents. While the results of the calculation of the level of centrality based on closeness centrality also 
obtained a high category value. This indicates that the closeness between actors in the network formed in institutional activities is evenly distributed, enabling a quick process of information exchange. Furthermore, the calculation of the centrality level based on betweenness centrality showed 14 respondents who can become actors/figures in spreading information to other institutional members. The correlation analysis Found that there was a strong relationship between social capital towards the decision of the retired Indonesian migrant workers to become an entrepreneur in Arjowilangun Village. This means that their high value of social capital influences the decision to do business for retired Indonesian migrant workers in Arjowilangun Village.

\section{ACKNOWLEDGMENT}

The authors gratefully acknowledge the Dean of Engineering Faculty and the Head of Research and Services Board for their support for this research

\section{REFERENCES}

[1] Badan Nasional Penempatan dan Perlindungan Tenaga Kerja Indonesia (BNP2TKI), "Period Workforce Placement Data (2011-2016)". [Online]. Accessed: http://www.bnp2tki.go.id/. 10 October 2017.

[2] C. Sander and S. M. Maimbo. (2003). Migrant Labor Remittances in Africa: Reducing Obstacles to Developmental Contributions, Washington D.C. World Bank, Africa Region Working Paper Series No. 64, Nov. 2003.

[3] E. Thobias, A. K. Tungka, and J. J. Rogahang. (2013). Pengaruh Modal Sosial Terhadap Perilaku Kewirausahaan. Jurnal Acta Diurna. Vol. 2(2), pp. 3746.

[4] L. Fatimah. (2017). Migrasi dan Pengaruhnya Terhadap Pola Pengasuhan Anak TKW di Dusun Pangganglele Desa Arjowilangun Kecamatan Kalipare Kabupaten Malang. AntroUnairDotNet. Vol. 6 (1), pp. 108-122.
[5] Setiadi, "Migran Kembali: Permasalahan Reintegrasi Sosial dan Ekonomi". Center for Population and Policy Studies Report, Gadjah Mada University, Yogyakarta, Indoneisa. CPPS S.303, July 12, 2001.

[7] T. M. Hapiz. (2014). Hubungan Tingkat Modal Sosial Terhadap Tingkat Pendapatan Pelaku UKM. Jurnal Mahasiswa Sosiologi. Vol. 3 (2), pp. 1-17.

[8] F. Maulana, "Pemanfaatan Modal Sosial Masyarakat pada Program Pembangunan Gampong (PPG) Kecamatan Bakti Barat Kabupaten Aceh Utara”. M.S. Thesis. Univ. Sumatera Utara. Medan, North Sumatra, Indonesia, 2009.

[9] I. R. D. Ari, "Participatory Approach to Community Based Water Supply System". Ph.D. Dissertation. Dept. of Urban Management, Grad. School of Engineering, Univ. of Kyoto. Kyoto, Japan, 2011.

[10] M. Wolcook, D. Narayan. (2000). Social Capital: Implication for Development Theory, Research, and Policy. The World Bank Research Observer. Vol. 15 (2), pp. 225-249.

[11] S. Wasserman, and K. Faust, "Social Network Analysis: Methods and Applications". Cambridge, England: Cambridge University Press. $1^{\text {st }}$ ed., 1994.

[12] J. P. Carrington, J. Scott and S. Wasserman, "Models and Methods in Social Network Analysis". Cambridge, England: Cambridge University Press. $9^{\text {th }}$ ed., 2012.

[13] S. Yamin, L. A. Rachmah, and H. Kurniawan, "Regresi dan Korelasi Dalam Genggaman Anda". Jakarta, Indoneisa: Salemba Empat Publisher, 2011.

[14] M. N. Scarborough, T. W. Zimmerer, and D. Wilson, "Effective Small Business Management". Harlow, England: Pearson Education Limited. $9^{\text {th }}$ edi., 2014.

[15] Suryana, "Kewirausahaan Pedoman Praktis: Kiat dan Proses Menuju Sukses". Jakarta, Indoneisa: Salemba Empat Publisher, 2006

[16] Y. Wihardja and D. Harjanti. (2016). Perilaku CV Anugerah Jaya dalam Menerapkan Modal Sosial untuk Pengembangan Bisnis. Jurnal AGORA. Vol. 4 (2), pp. 224-229. 